\title{
Inhalt
}

\section{A. Sprechbildung}

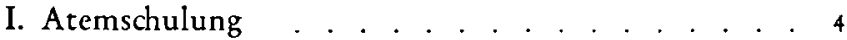

1. Die Sprechatmung . . . . . . . . . . . . . 4

2. Grundsätze . . . . . . . . . . . . . . . . 12

3. Atemübungen . . . . . . . . . . . . . . 13

II. Stimmbildung . . . . . . . . . . . . . 15

1. Bau und Funktion des Kehlkopfes. . . . . . . . . . 15

2. Stimmeinsatz . . . . . . . . . . . . . . . . 19

3. Resonanz . . . . . . . . . . . . . . . . . 21

4. Stimmansatz . . . . . . . . . . . . . . . 22

5. Indifferenzlage . . . . . . . . . . . . . . 25

6. Grundsätze . . . . . . . . . . . . . 26

7. Stimmübungen . . . . . . . . . . . . . . . . 28

III. Lautbildung . . . . . . . . . . . . . . . . 31

1. Buchstabenwert und Lautwert . . . . . . . . . . 32

2. Koartikulation . . . . . . . . . . . . . . . 33

3. Vokale und Konsonanten. . . . . . . . . . . . . 34

4. Besondere Schwierigkeiten in der Bildungsweise. . . . . 38

5. Lautbildungsübungen . . . . . . . . . . . . . 45

6. Gemeingeltung und Formstufe . . . . . . . . . . . 47

\section{B. Sprechleistung}

I. Der Ausspruch . . . . . . . . . . . . . . . . 52

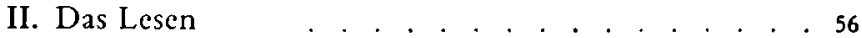

1. Sinnfassendes Lesen . . . . . . . . . . . . 56

a) Lautung, Betonung, Sprechart . . . . . . . . 58

b) Gliederung und Abstufung . . . . . . . . . . . . 62

2. Textnoticrung . . . . . . . . . . . . . . 67

3. Leitsätze . . . . . . . . . . . . . . . . 70

4. Lescfehler . . . . . . . . . . . . . 70

5. Ubungshinweise . . . . . . . . . . . . . . 72

6. Hinwcise zum Dichtungssprechen . . . . . . . . . . 73

III. Das freie Sprechen . . . . . . . . . . . . . . 77

1. Das Sprechdenken . . . . . . . . . . . . 78

2. Fehlformen . . . . . . . . . . 80

3. Obungshinweise . . . . . . . . . . . . . . . . 81

Nachwort . . . . . . . . . . . . . . . . . . . . 89

Anmerkungen . . . . . . . . . . . . . . . . 95

Literaturverzeichnis . . . . . . . . . . . . . 101 